\title{
荒川に打ける砂礫堆の分有と形態について*
}

小峰夏水

1. 序 山地が解體され放出され它物質は流水によつて砂礫として運般

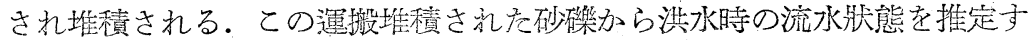

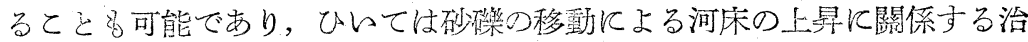

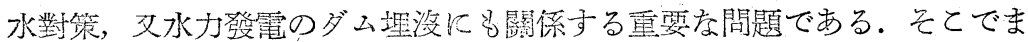
ず砂礫の移動によつて生じた河床の砂磁堆について荒川の中流をえらんで 鬥盖し，若干の考察を行つた.

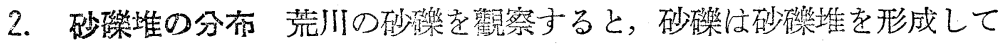
いる. 砂磁堆といらのは Fig. 1 のように砂丘に似た形態を現わし，上流 側飞綬勾配 (砂礫堆の背)，下流 側に急勾配（砂礫堆の頭）であ る.とのよら变砂礫堆の分仿走 調查した（Fig. 2)。

これらの分质の下流限界は鴻 巢附近で，ここは常水路の幅が 㷋く索つているので水深は大と 交り，乙のために砂礘堆を夕る

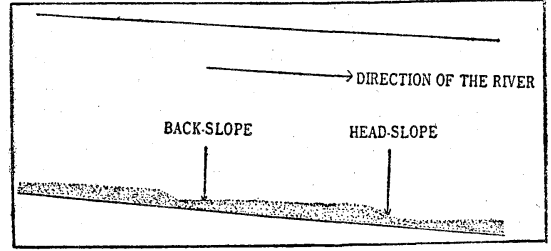

Fig. 1. Model of the longitudinal section of gravelbank.

ととが出來疗い。

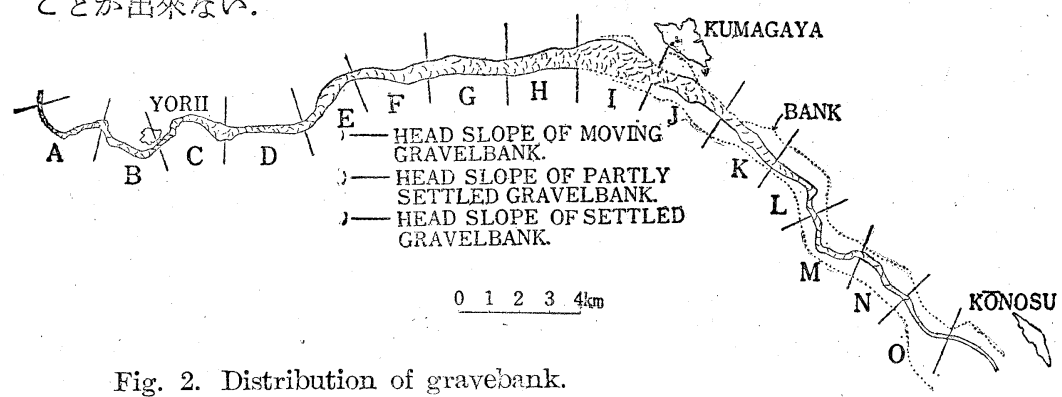

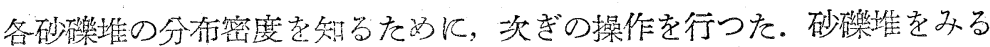
下流の最後の所を基準として $2 \mathrm{~km}$ の距離で區分し, 各區について砂碟堆

* 率京文理科大學地理學呚室 自然科學砄究費業續. 要旨は䀡和 25 年 9 月の日本 地理學會例會に於て，發表した。

** 賏京都下 三㕍市市立高等學校 


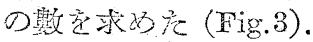

移動砂碩堆方玉 $\mathrm{E} \cdot \mathrm{F}$

凅ではやや數が少くな つているが，てれは鼻 山の所任約 $2 \mathrm{~m}$ の高度 差を多つ人工堰があ り，之の人工堰が移動 砂硶堆の移動を阻止し てレるためである。こ れがなければ，D區ふ らエ區に漸增子るもの 上思わ机る。
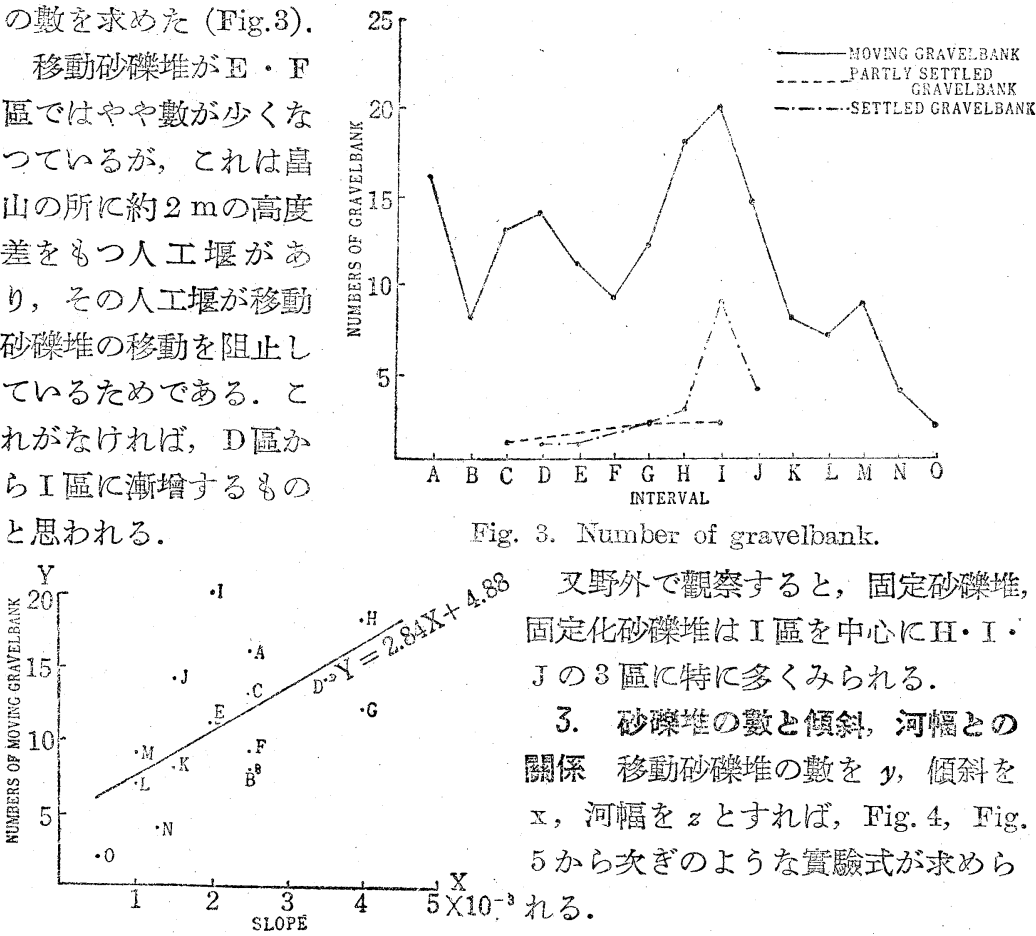

Fig. 4. Relation between of moving

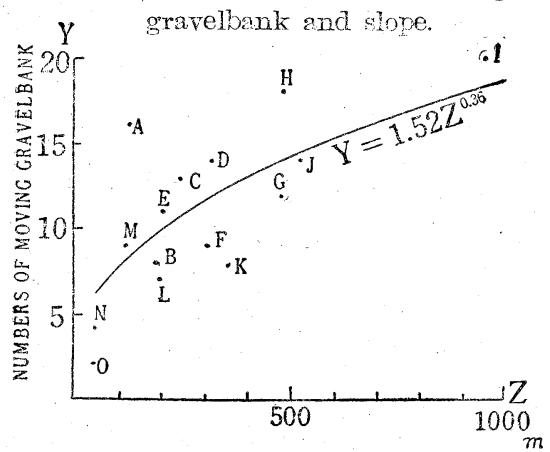

Fig. 5. Relation between numbers of moving gravelbank and wiath of the river.
毁ち，秋動砂礫堆と㑯科とは

$$
y=2.84 x+4.88
$$

秋動砂磞堆と河幅と忙

$$
y=1.52 z^{0.36} \text { である. }
$$

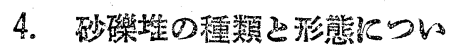

て 砂磞堆をこの性質ふら次ぎの 種類に分けて述べる。

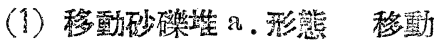
砂磞堆(移動砂洲 1)，漂砂堆 2) と

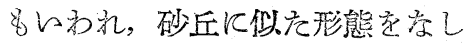
ているの梳迅の通りである。移

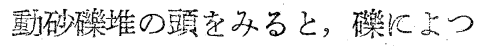
て形线さ礼ている名のと，又砂が 


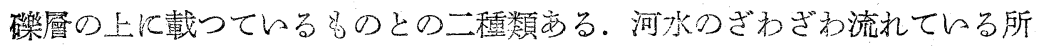

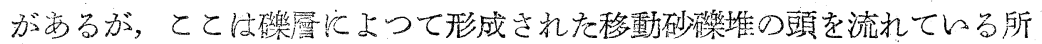
である。

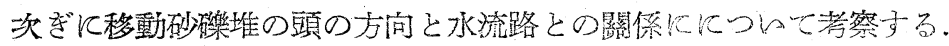
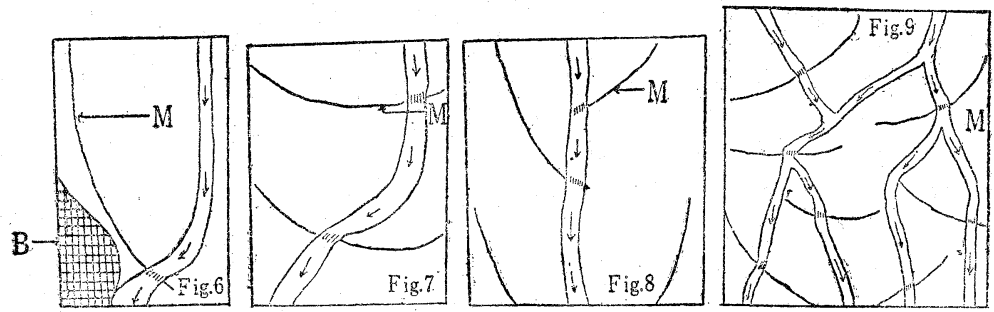

Figs. 6 9. Moving gravelbank. $M=$ moving gravelbank, $B=$ bank

Fig. 6 は金尾附近に2る型式で，との型恃此較的上流區に多くあり，移

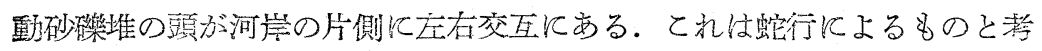
えられる。

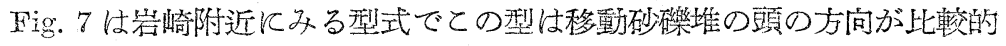

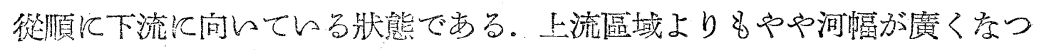

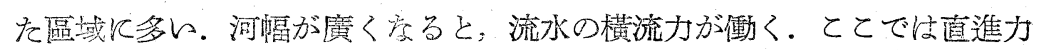
より横流力が弱いたに下流側反间く8のと思われる.

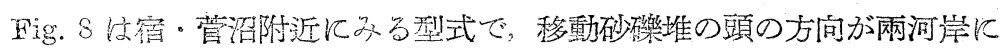
向いていら。との型式は河蝠が廣くなり, 横流力が直進力より强く左右に

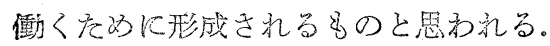

Fig. 9 は熊谷上流 $2 \mathrm{~km}$ の區域附近にみる型式で, 移動砂磁堆が多く集

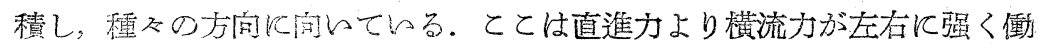

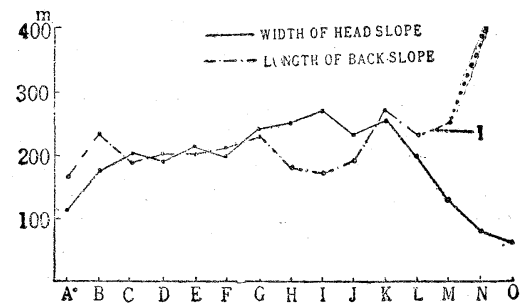

Fig. 10. Width of headi-slope and length of back-slope in moving gravelbank. $I=$ intermittence
を，又橫流力が幾種類に徽くため に種々の方向に向いているものと思 予れる。文減水時の流水は網狀流路 を示している。

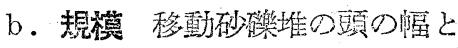
背の長さ奖測定し，各區の平均值を 求邓 Fig. 10 亿示した.

初めに移動砂礫堆の頭の輻につ々 て教察する. I 區即亏熊谷上流 $2 \mathrm{~km}$ 
の所で最大となり，K區（特に新川附近）から下流に急激に小さく空る。 次ぎに移動砂碩堆の背の長さについて教察すると，H・I區の所で短く なり，几區附近から急激に長くなつている．とて牥常時冠水しているため に背の部分はよく觀察出來ないが断續的に孝つていると解釋される。

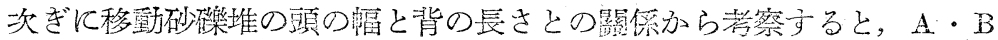
區では頭の幅よりも背の長さが大となつている。此處流水の直淮力が棈 流力より大であるために背の部分が發達し, 而直進力が大であると共に河

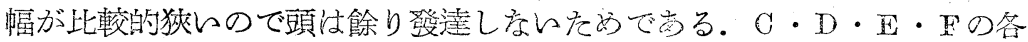
區で惊頭の幅と背の長さが大體同じ位でする。との區域では上流部に比較 して河幅が廣く，父頭も發達している。ことは直進力と横流力が大樶同じ 强さで衝くためで每る。H・I・J區では頭の幅が背の長さより大となつ ている．との區では河幅が廣くなつているから，流水の力は横流力の方が

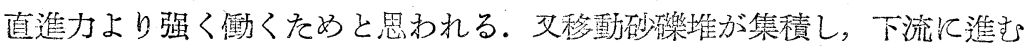

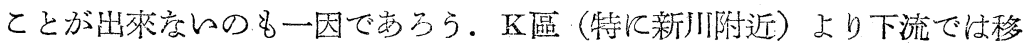
動砂礫堆の頭の幅が急激に小になり, 又背の長さは前远した通り斷續的に なつている．即ち移動砂磁堆の形が小になつている.

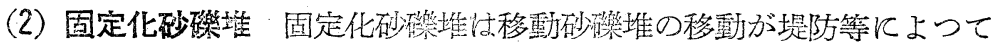

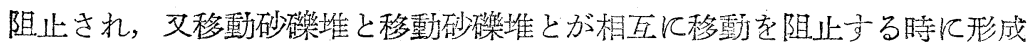
される，固定化砂燳堆の頭には「すぎな」が最も多く生育し，其の优「め

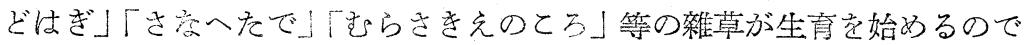
容易に發見するととが出來る。

Fig. 11 は堤防によつて移動砂礫堆の移動が阻止された狀態である.乙 のよう学固定化砂燳堆の附近 では河幅が廣く, 罀流力が發 道し，直進力は弱く移動出來 ずに固定化する。

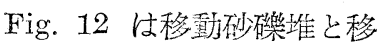
動砂繁堆とが相互に移䣦を阻 止し固定化した狀態である。

(3) 固定砂燳堆 固定砂磕

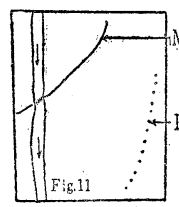

Figs. 11 13 Partly settled and settled. gravelbanks. $M=$ moving gravelbank. $\mathrm{P}=$ partly settled gravelbank.

$\mathrm{S}=$ settled gravelbank.

堆驻固定化砂碟堆が更に進んだもので，その表面の牛分以上に固定化砂磁 堆面と同じ雜草が生育している場合をよんだ，更に發達すると「はり充ん じゅ」のような灌杚もふるととがある（Fig. 13)。 


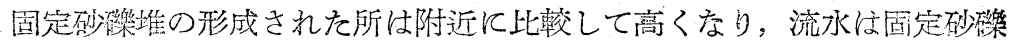

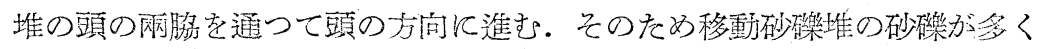

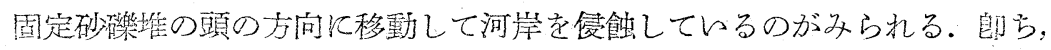

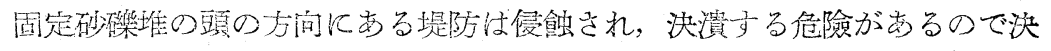
潰する以前に豫防措置を埥ずる必要がある.

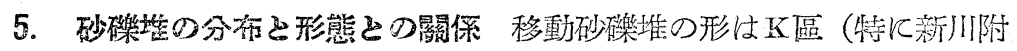
近）加ら下流飞急激に小さくなつている。乙の急激孝變化はI區，郎ち熊 谷上流 $2 \mathrm{~km}$ の區域を中心に多量の砂磂堆が集積し，河幅が廣いととも手

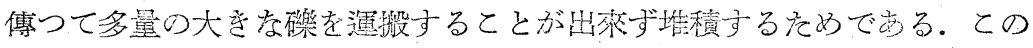

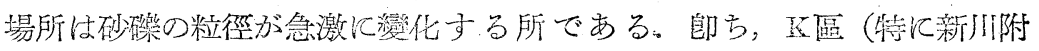

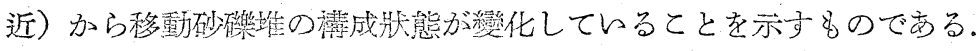

6. 結語 砂磂堆の分布, 形態について考察した。 その結果, 次ぎのよ ら宗とと至知るととが出來た。

1）熊谷上流 $2 \mathrm{~km}$ の區域に砂碩堆が多く箱積している. 治水對策の上

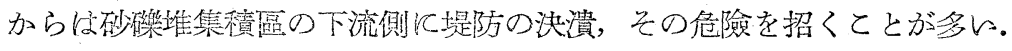

2）移勸砂礫堆の數と傾斜，河幅との關係は次ぎの如くでする.

郎亏，移彭砂础堆の数 $=y$ 傾斜 $=\mathrm{x}$ 河幅 $=\boldsymbol{z}$ とすれば

$$
y=2.84 x+4.88 \quad y=1.52 z^{0.26}
$$

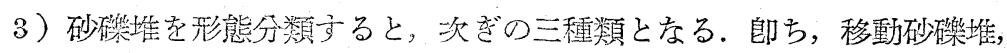

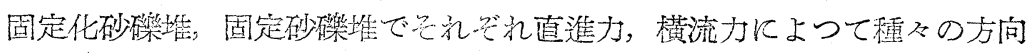
に角々ている。治水對策として呞部的ではあるが，固定砂碑堆の頭の方向 に西る堤防は侵創され，決漬する危險があるので決潰する以前飞豫防措置

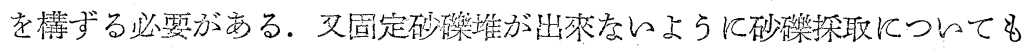

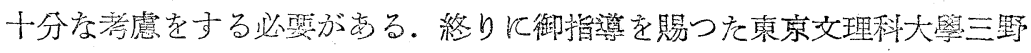
博士に感謝の意态表する。

（昭和 26 年 11 月 28 日受理）

參考文獻 (1) 三野與吉 : 天井川堤防決潰の要因と對筮，香川縣財田川の場合， 日本地理學會 3 月例會 1949.（2）君鼻八 㓺: 地表水 1944. pp. 359 360.

On the Distribution and Form of Gravelbanks in Arakawa, Kanto District.

\section{Isamu Komine*}

The writer studied on the gravelbanks-their distribution, their forms, * Mitaka High School, Tokyo. 
etc.-along the middle course of the Arakawa. The results are as follows:

1) Many gravelbanks are crowded in the upper course 2 kilometers up from Kumagaya. This section is susceptible of breakdown of artificial banks, as we have many examples, and the weekpoint exists just below the crowded gravelbanks (Fig. 2).

2) Relation between the gravelbanks and its gradient

Numbers of moving gravelbanks................

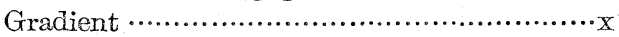

As a result of the calculation, the empirical formula will be as follows: $y=2.84 x+4.88$ (Fig. 4)

3) Relation between gravelbanks and the width of the river.

Numbers of gravelbanks.........................

Width of the river ….........................

The empirical formula will be as follows:

$\mathrm{y}=1.52 \mathrm{z}^{0 \cdot 36}$ (Fig. 5)

4) Moving gravelbank

a) Relation between the direction of the moving gravelbank head-slope and the stream (Fig. 6. 7. 8. 9.).

b) Relation between the width of the moving gravelbank head-slope and the length of the back-slope (Fig. 10).

5) Partly settled gravelbanks are formed when the moving gravelbanks are prevented by the artificial bank, or the moving gravelbanks prevent their movement each other (Fig. 11. 12).

6) Settled gravelbanks are the advanced form of the partly settled gravelbanks. There can be seen weeds growing on more than half of their whole surface, among which are Equisetum arvensel, Lespedeza sericea miq, and Setaria viridis Beaw, which are characteristic of these settled gravelbanks.

Once a settled gravelbank is formed, it becomes higher than the moving gravelbanks in the neighbourhood. Streams flow along the head-slope of the settled gravelbank. There are gravels of the moving gravelbank, that may destroy the bank or the shores of the river by moving along and downward the direction of the head-slope (Fig. 13).

7) Relation between distribution and forms of the moving gravelbanks. Forms of the moving gravelbanks become rapidly small down from $K$ region.

It is concluded, therefore, that this rapid variation is caused by many gravelbanks been $2 \mathrm{~km}$ upstream from Kumagaya, on one side, and the greater width of the river, on the other, so that the stream can not transport big gravels, because there are many gravelbanks. So there is a big difference of the gravelbank conditions between above and below the $K$ region. 